\title{
UNCONSTITUTIONAI CONDITIONS
}

\author{
MaUrice H. Merrill
}

Dictum, oft repeated, tends to crystallize into a rule of law. A rule, so crystallized, is given judicial application, often without detailed consideration of its foundations or proper limits. A time comes when able and ingenious counsel, zealous for the cause in which they are retained, seek to extend the application of the rule far beyond the limits of the sphere within which it arose. The use of familiar phraseology may lead the court to acquiesce, seemingly at least, without adequate investigation of the basis for the new extension or of possible conflicts with other well-established lines of decision. In this manner, imperceptibly and without arousing attention at the time, decisions and dicta at variance with doctrines long regarded as established find place in the fabric of the law. ${ }^{1}$ When this occurs, it is necessary to work out in some. fashion a reconciliation of the old and the new lines of decision, or, if this attempt fails, to determine which deserves to survive. Such a situation seems to have arisen in connection with the recent development of the doctrine of unconstitutional conditions.

\section{Origin ANd Development}

The genesis and the early development of the doctrine have been dealt with adequately and in great detail elsewhere. ${ }^{2}$ Here it is necessary to give only such a summary as may be requisite to an adequate presentation of the problem to be discussed. The story begins with the efforts put forth by many states to prevent foreign corporations doing business within their boundaries from resorting to the federal courts. The orthodox American doctrine

${ }^{1} \mathrm{Mr}$. Charles Warren has given us an excellent account of sich a process in another field of constitutional law. See Warren, The New "Liberty" Under the Fourteenth Amendment (1926) 39 HARv. L. REv. 43I, to which Fiske v. Kansas, 274 U. S. 380, 47 Sup. Ct. 655 (1927), affords an interesting sequel. See also Whitney v. California, 274 U. S. 357, 371, 47 Sup. Ct. 641, 646 (1927).

2 See Henderson, The Position of Foreign Corporations in American Constitutional LaW (I918) c. 8. 
that the right of a foreign corporation to transact business within the boundaries of a state depends entirely upon the state's permission ${ }^{3}$ seemed to offer a means of accomplishing the desired result. If the states had power to refuse admittance to foreign corporations entirely, with or without cause, surely they might exact in return for admission whatever boon they wished. ${ }^{4}$ If so, a promise, prior to admission, not to resort to the federal courts, or a liability to expulsion in case of such a resort, required as the price of admission, would seem to be a legitimate and effective means of attaining the desired end. ${ }^{5}$ The states were not slow to try out this method. Naturally the corporations resisted, and in the case of Insurance Co. v. Morse ${ }^{6}$ the Supreme Court of the United States held void a statute requiring an agreement not to remove suits to the federal courts as a condition precedent to admission. This decision was based upon the ground, supported by dicta expressed in two earlier cases, ${ }^{7}$ that the exaction of the agreement was an attempt to interfere with the exercise of a right derived from the Constitution and the laws of the United States. While the term "unconstitutional condition" was not specifically employed in the opinion, the case seems clearly to be the fountainhead of the doctrine which now goes by that name.

${ }^{3}$ Paul v. Virginia, 8 Wall. I68 (U. S. I868). Of course, the statement assumes the usual exceptions to the rule. See Burdick, THE LAw of THE AMERTCAN CONSTITUTION (I922) 484.

- Cf. Henderson, op. cit. silpra note 2, at 133 .

'See argument of counsel for the defendant in error in Insurance Co. v. Morse, 20 Wall. 445, 447 (U. S. 1874), and the dissenting opinion of Waite, C. J., at 458 . (I887).

${ }^{6}$ Supra note 5. Accord: Barron v. Burnside, I21 U. S. I86, 7 Sup. Ct. 93 I

7 "A corporation created by Indiana can transact business in Ohio only with the consent, express or implied, of the latter State, 13 Pet. 519. This consent may be accompanied by such conditions as Ohio may think fit to impose; and these conditions must be deemed valid and effectual by other states, and by this court, provided they are not repugnant to the constitution or laws of the United States, or inconsistent with those rules of public law which secure the jurisdiction and authority of each State from encroachment by all others, or that principle of natural justice which forbids condemnation without opportunity for defence." Lafayette Ins. Co. v. French, I8 How. 404, 407 (U. S. 1855).

"The power of the State to discriminate between her own domestic corporations and those of other States, desirous of transacting business within her jurisdiction, is clearly established. . . . As to the nature or degree of discrinnination, it belongs to the State to determine, subject only to such limitations on her sovereignty as may be found in the fundamental law of the Cinion." Ducat v. Chicago, 1o Wall. 410, 415 (U. S. I870). 
After some vacillation, and after attempts at distinction between requiring an agreement not to resort to the federal courts as a condition precedent to admission and ouster after admission for resorting to such courts, ${ }^{8}$ and between corporations engaged solely in intrastate commerce and those engaged in both interstate and intrastate business, ${ }^{9}$ it has been definitely decided within the last decade that neither directly nor indirectly may the state condition its grant of entry to the foreign corporation upon the forbearance of the latter to resort to the national courts. ${ }^{10}$ The actual decisions in these cases do not involve any sweeping denial of state power to require a surrender of constitutional privilege in return for favors granted. They merely forbid the states to condition their grants upon agreement not to resort to the federal courts. The use of state bargaining power to discourage or to restrict recourse to the federal tribunals might well be considered so inconsistent with the efficient functioning of the governmental system set up by the Constitution of the United States as to be forbidden by that document. ${ }^{11}$ A similar explanation may be made of many other decisions in which the doctrine of unconstitutional conditions has been invoked. Thus states have been forbidden to condition the entry of foreign corporations upon assent to taxes, or to other conditions which burden interstate commerce, ${ }^{12}$ or upon submission to regulation of conduct

\footnotetext{
${ }^{8}$ Doyle v. Continental Ins. Co., 94 U. S. 535 (I876) ; Security Mut. I. Ins. Co. v. Prewitt, 202 U. S. 246, 26 Sup. Ct. 619 (I90I).

${ }^{\circ}$ Harrison y. St. Louis \& S. F. R. R., 232 U. S. 318, 34 Sup. Ct. 333 (19r3); cf. Donald v. Philadelphia \& R. C. \& I. Co., 241 U. S. 329,36 Sup. Ct. 563 (rgi6).

${ }^{10}$ Terral v. Burke Const. Co., 257 U. S. 529, 42 Sup. Ct. I88 (I922).

I' See HeNDERSON, op. cit, sufra note 2, at I4I, I42, for a fuller exposition of this view.

${ }^{12}$ Western Union Tel. Co, v. Kansas, 216 U. S. I, 30 Sup. Ct. I90 (1910) (tax); Pullman Co. v. Kansas, 216 U. S. 56, 30 Sup. Ct. 232 (1910) (tax); Ludwig v. Western Union Tel. Co., 216 U. S. 146, 30 Sup. Ct. 280 (19ro) (tax) ; Looney. v. Crane Co., 245 U. S. 178, 38 Sup. Ct. 85 (Ig17) (tax); Sioux Remedy Co. v. Cope, 235 U. S. I97, 35 Sup. Ct. 57 (I914) (payment of license fee and appointment of resident service agent as condition to suing in state court to enforce interstate contract); Dahnke-Walker Mill. Co. v. Bondurant, 257 U. S. 282, 42 Sup. Ct. 106 (I92I) (same); Western Union Tel. Co. v. Foster, 247 U. S. 105, 38 Sup. Ct. 438 (1918) (regulation of interstate commerce in return for use of streets); International Paper Co. v. Mass., 246 U. S. 135, 38 Sup. Ct. 292 (IgI8) (tax).
} 
outside the state, ${ }^{13}$ or upon allowing the state to tax property situated beyond its borders. ${ }^{14}$ The free conduct of interstate commerce, liberty of access to the national courts, freedom of the states from forays by each other into their respective territorial domains over conduct and taxation, are bound up with the working of the division of powers among the states and between the states and the central government. The use of state power to interfere with this apportionment, even by way of bargaining, seems properly to be held beyond the pale of the Constitution. But such a view is by no means inconsistent with permitting the exchange of favors in return for a surrender of constitutional privileges not bound up with the working of our system of divided governmental functions.

The language advanced in support of the decisions does not, however, limit the doctrine to the preservation of the federal system against state encroachment. On the contrary, broad terms have been used from the beginning, indicative of a view that the doctrine may be employed by foreign corporations to oppose attempts to force the waiver of any constitutional privilege, whatever its character, as the price of admission. As we have seen, the dicta upon which the first decision was based excepted all conditions "repugnant to the Constitution and laws of the United States" from the states' bargaining power, ${ }^{15}$ and that case itself contains language equally broad in its significance. ${ }^{16}$ Later pronouncements were still more sweeping. ${ }^{17}$ The prophecy of the

\footnotetext{
${ }^{13}$ Fidelity \& Deposit Co. v. Tafoya, 270 U. S. 426, 46 Sup. Ct. 33I (1926).

${ }^{14}$ Western Union Tel. Co. v. Kansas, supra note 12 ; Looney v. Crane Co., supra note I2.

${ }^{15}$ See extracts set out supra note 7 .

${ }^{10}$ "None of the cases so much as intimate that conditions may be imposed which are repugnant to the Constitution and laws of the United States, or inconsistent with those rules of public law which secure the jurisdiction and authority of each State from encroachment by others." Insurance Co. v. Morse, supra note 5 , at 457 .

${ }_{17}$ "As the Iowa statute makes the right to a permit dependent upon the surrender by the foreign corporation of a privilege secured to it by the Constitution and laws of the United States, the statute requiring the permit must be held to be void." . Barron v. Burnside, stipra note 6 , at 200,7 Sup. Ct. at 936.

"But that statute, requiring the corporation, as a condition precedent to obtaining a permit to do business within the State, to surrender a right and privilege secured to it by the Constitution and laws of the United States, was unconstitutional and void. . . " Southern Pac. Co. v. Denton, I46 U. S. 202, 207, 13 Sup. Ct. 44,46 (1892).
} 
doctrine's expanded scope contained in these pronouncements seems fulfilled by recent decisions forbidding the states to barter admission to foreign corporations in return for the surrender of the equal protection clause of the Fourteenth Amendment, ${ }^{18}$ a provision which it is impossible to regard as related in any respect to the proper operation of the federal system.

It has been suggested that the result of forbidding the states to exact a relinquishment of any constitutional privilege in return for admission is to establish the abandonment of "the traditional doctrine that a foreign corporation can be excluded at the will of the state." 19 Certainly such cases as Kentucky Finance Corp. $\%$. Paramount Auto Exchange Corp. ${ }^{20}$ go far to suggest such a result, and force us to admit a seeming merit in the contention that, when one cannot legally exact the price he pleases in return for the grant of a privilege, that privilege is no longer within his control.21 But, however logical such a deduction from the cases may appear, it quite evidently does not accord with the conception of the doctrine entertained by the Supreme Court. In none of the cases is there a general denial of the power to exclude, and the

". . the requirement . . . compelled the company, in order that it - might do local business ... to waive its constitutional exemption from state taxation on its interstate business and on its property outside of the State . . the State could no more exact such a waiver than it could prescribe as a condition of the company's right to do local business in Kansas that it agree to waive the constitutional guaranty of the equal protection of the laws, or the guaranty against being deprived of its property otherwise than by due process of law." Pullman Co. v. Kansas, supra note 12, at 62, 30 Sup. Ct. at 234 .

"For example, a state may not say to a foreign corporation, you may do business within our borders if you permit your property to be taken without due process of law, or you may transact business in interstate commerce subject to the regulatory power of the state." Baltic Min. Co. v. Mass., $23 I$ U. S. 68, 83, 34 Sup. Ct. I5, i8 (1913).

${ }^{23}$ Air-Way E. A. Corp. y. Day, 266 U. S. 71, 45 Sup. Ct. I2 (1924) (tax statute) ; Hanover F. Ins. Co. v. Harding, 272 U. S. 494, 47 Sup. Ct. I79 (I926) (same) ; Power Mfg. Co. v. Saunders, 274 U. S. 490, 47 Sup. Ct. 678 (1927) (venue statute); Quaker City Cab Co. v. Pa., 277 U. S. 389, 48 Sup. Ct. 553 (r928) (tax statute).

${ }^{20}$ See Henderson, op. cit. supra note 2, at 147 .

${ }^{20} 262$ U. S. 544, 43 Sup. Ct. 636 (1923), holding that a foreign corporation could not be prevented from coming into a state to assert its title to property situated therein by suit in the state courts and that, on such entry, the foreign corporation became a person within the state's jurisdiction and therefore entitled to "the equal protection of the laws."

${ }^{2}$ See Henderson, op. cit. supra note 2, at I47. In (1928) I6 Calif. L. REv. 428, 43I, it is stated that: "The waiver of a right can not be attached to the commission of an act which the state has no power to prevent." 
recent decisions of the Court indicate that it continues to regard entry into a state by a foreign corporation as a privilege which the state may deny or may grant upon condition, provided the condition does not fall within the class described as "unconstitutional." ${ }^{22}$ At the most, this interpretation of the cases represents a position that may be taken in the future; it does not appear to constitute the law of today.

\section{Limits of the Modern Extension}

If the doctrine be viewed as affording protection against the "trading off" of constitutional privileges, it seems logical to inquire why it should be restricted to grants of admission, or why foreign corporations alone should be regarded as entitled to its protection. If the protection of the Constitution be too precious to be bartered away by foreign corporations, is it not equally so with respect to domestic corporations, and still more with respect to the individual? And if constitutional privileges may not be bargained away in return for the privilege of doing business within the state, is there any other favor or benefit within the control of the state for which they may be exchanged? Logic seems to indicate a negative answer. We should, therefore, expect to find that astute counsel would argue for such a widened application of the doctrine, and we should not be too surprised if their argument be regarded as meritorious by the Court.

This point in the extension of the unconstitutional condition doctrine appears to have been reached in Frost \& Frost Trucking Co. v. Railroad Comm. ${ }^{23}$ In that case was involved the validity of a statute of California requiring a certificate of public convenience and necessity to be secured by carriers, whether common or private, as a prerequisite to carrying on their business over the public highways of the state. The act was interpreted by the Supreme Court as imposing upon the applicant the obligation to assume the duties and liabilities of a common car-

${ }_{22}^{2}$ E. g. Interstate Amusement Co. v. Albert, 239 U. S. 560, 36 Sup. Ct. 168 (1916) ; Munday v. Wisconsin Trust Co., 252 U. S. 499, 40 Sup. Ct. 365 (1920); Bothwell v. Buckbee Mears Co., 275 U.'S. 274, 48 Sup. Ct. 124 (I927) ; Hemphill v. Orloff, 277 U. S. 537,48 Sup. Ct. 577 (I928).

${ }^{23} 27$ I U. S. 583,46 Sup. Ct. 605 (1926). 
rier as a condition precedent to the issuance of the certificate. It held the statute, so construed, unconstitutional, primarily on the ground that to force the status of a common carrier upon a private carrier against his will amounts to deprivation of property without due process of law. ${ }^{24}$ To the suggestion that, as the state might deny the use of its highways altogether to carriers, ${ }^{25}$ it might make its permission conditional upon assumption of the public utility status, the Court responded that to do so would be using the power of refusal to reach a forbidden result, and hence would itself be unconstitutional.

The case has been criticized with apparent soundness on the ground that the requirement of the certificate was separable from the remainder of the act, making it unnecessary to consider the attempted imposition of common carrier duties, ${ }^{26}$ but this criticism in no way detracts from the significance of the Court's position. The six justices forming the majority of the Court may have mistaken the question before them, but there is no doubt as to their solution of the question that they thought was before them. Upon that point the language of Mr. Justice Sutherland, speaking for the majority, is significant:

"It is not necessary to challenge the proposition that, as a general rule, the state, having power to deny as a privilege altogether, may grant it upon such conditions as it sees fit to impose; but the power of the state in that respect is not unlimited, and one of the limitations is that it may not impose conditions which require the relinquishment of constitutional rights. If the state may compel the surrender of one constitutional right as a condition of its favor, it may, in like manner, compel a surrender of all. It is inconceivable that guaranties embedded in the Constitution of the United "States may thus be manipulated out of existence." 27

This is surely an unequivocal adoption of the view that all privileges vouchsafed by the Federal Constitution are beyond the

${ }^{24}$ See Michigan P. U. Comm. v. Duke, 266 U. S. 57c, 577, 45 Sup. Ct. I9I, 193 (I925).

This was assumed for the purposes of the case. Supra note 23, at 592, 46 Sup. Ct. at 607 .

Es See (I926) 40 Harv. L. Rev. 13I ; (1927) II Minn. L. Rev. 555.

27 Supra note 23, at 593, 46 Sup. Ct. at 607 . 
bargaining power of the state. It squarely declares that, though the state may have privileges within its control which it may withhold at will, it cannot use a grant of those privileges to secure a valid consent to acts which, if imposed upon the grantee in invitum, would be beyond its constitutional power. Whether the grantee is a natural or an artificial person is entirely immaterial. Equally without significance is the nature of the constitutional privilege affected by the prescribed action.

But when given this broad scope the doctrine enunciated in the Frost case runs squarely afoul of numerous lines of decision. Although there are dicta in three cases which seem to foreshadow it, $^{28}$ the decision in the Frost case, in addition to marking the first application of the unconstitutional condition doctrine to the protection of all constitutional privileges, actually conflicts with such a well-established current of adjudication that it is difficult to see how both can survive in the body of our constitutional law.

The cases holding that a domestic corporation may not question the validity of provisions of the law under which it is incorporated may perhaps be distinguished upon the ground that the creature may not question the creative act. ${ }^{29}$ Yet, since domestic corporations are entitled to the protection of the Constitution, ${ }^{30}$ it seems that they should be in as strong a position to disavow a waiver of constitutional privileges when exacted as the price of their corporate existence as when made in return for the grant of any other favor. ${ }^{31}$ Hence it seems entirely proper to regard

${ }^{28}$ See W. W. Cargill Co. v. Minn., I80 U. S. 452, 468, 2I Sup. Ct. 423, 429 (IgoI); Kansas City, M. \& B. R. R. v. Stiles, 242 U. S. III, II7, 37 Sup. Ct. 58, 60 (I9I6) ; Board of Pub. Util. Com'rs v. Ynchausti \& Co., 25I U. S. 401, 404, 40 Sup. Ct. 277,278 (1920).

${ }^{20}$ Chicago, R. I. \& P. Ry. v. Zernecke, I83 U. S. 582, 22 Sup. Ct. 229 (I902) (railroad may not question provision of incorporation imposing absolute liability for injury to passengers) ; Interstate Consol. St. Ry. v. Mass., 207 U. S. 79, 28 Sup. Ct. 26 (I907) (corporation may not question validity of rate-fixing provision in its charter) ; International \& G. N. Ry. v. Anderson County, $246 \mathrm{U}$. S. 424,38 Sup. Ct. 370 (Igr8) (provision in charter relative to removal of railroad shops and offices); see Roberts \& Schaeffer Co. v. Emmerson, 27 I U. S. 50, 54, 46 Sup. Ct. 375,376 (1926) (domestic corporation franchise tax as denying equal protection).

${ }^{30}$ Covington \& Lexington Turnpike Rd. Co. v. Sandford, I64 U. S. 578, I7 Sup. Ct. 198 (1896).

"s See suggestion to this effect by Holmes, J., in Interstate Consol. St. Ry. v. Mass., supra note 29, at 85, 28 Sup. Ct. at 27 . See also Day, J., in Kansas City, M. \& B. R. R. v. Stiles, sitpra note 28 , at II7, 37 Sup. Ct. at 60 . 
these cases as in conflict with the principles enunciated in the Frost case.

In other decisions we find still more clear-cut opposition to the broadened doctrine of unconstitutional conditions. A state may exact as a condition to the admission of a foreign corporation that it abide by the state's anti-trust laws, irrespective of the question whether those laws arbitrarily restrain freedom of contract in violation of the Fourteenth Amendment. ${ }^{32}$ The same is true of regulations affecting the making of insurance contracts. ${ }^{33}$ Congress may require relinquishment by the grantee of claims to other land as a condition to a land grant, although the grantee has acquired "vested rights" to such land not subject to destruction by Congress without the grantee's consent. ${ }^{34}$ In return for the grant to a pipe line, built to convey oil to a particular refinery, of the power of eminent domain and the right to transport oil, the state may require it to assume the obligations of a common carrier; ${ }^{35}$ a result that seems almost squarely in conflict with the Frost decision. The benefits of an elective workmen's compensation act may be bartered for a surrender of the right to due process in judicial review of the decisions of an administrative tribunal. ${ }^{38}$ A riparian owner, having by the local law no right to erect a dam without the state's consent, may be required, in return for such consent, to agree to future acquisition by the state of the dam site, flowage rights, and property used in connection therewith at a valuation below that to which he would be constitutionally entitled upon a compulsory taking. ${ }^{37}$ So the withholding of franchise privileges which a city has within its control may be used as an inducement to the sale of property at a reduced

\footnotetext{
4 3s Humbird v. Avery, 195 U. S. 480, 25 Sup. Ct. 123 (1904).

${ }^{35}$ Pierce Oil Corp. v. Phoenix Ref. Co., 259 U. S. 125, 42 Sup. Ct. 140 (1922); see Pipe Line Cases, 234 U. S. 548, 561, 34 Sup. Ct. 956, 958 (rgr.4).

${ }^{38}$ Booth Fisheries Co. v. Industrial Comm., 27I U. S. 208, 46 Sup. Ct. 491 (Ig26) ; cf. Oceanic St. Nav. Co. v. Stranahan, 214 U. S. 320, 29 Sup. Ct. 671 (Ig09) (in the realm of federal power).

${ }^{37}$ Fox River Paper Co. vi Railroad Comm., 274 U. S. 65r, 47 Sup. Ct. 669
} (1901).

${ }^{32}$ Waters-Pierce Oil Co. v. Texas, I77 U. S. 28, 20 Sup. Ct. 518 (1900).

${ }^{33}$ Haricock Mut. Life Ins, Co. v. Warren, I8I U. S. 73, 2I Sup. Ct. 535 (1927). "Compliance with $\$ 3 \mathrm{I} .09$ is the price which plaintiffs must pay to secure the right to maintain their dam." Ibid. 657, 47 Sup. Ct. at 67I. 
price. $^{38}$ And there are numerous cases holding that public utilities may, in return for franchise grants, contract away their right to a "non-confiscatory" rate under the Fourteenth Amendment. ${ }^{39}$

All these cases seem irreconcilably opposed to the doctrine of the Frost case. In all of them the privilege waived was one which. the Court held protected by the Constitution against enforced deprivation. In all of them, the waiver was made in return for the grant by the state of some benefit which it was privileged to give or to withhold. It seems incontrovertible that if the doctrine of the Frost case is to stand these cases must fall. That the overthrow of this line of decision was not contemplated by the Supreme Court appears evident from the fact that the list contains cases practically contemporaneous' with, and even subsequent to, the Frost case. In such a state of the authorities it is proper to consider the arguments favoring each of the competing doctrines in order to determine which is worthy of survival.

\section{Resolution of the Conflicting Forces}

The argument in favor of the broad application of the unconstitutional condition rule is the familiar policy against accomplishing a forbidden result by indirection. If the state may not enforce its will upon these matters without the consent of those affected, may it grant or withhold favors as a means of extorting a consent which would not be given freely without such pressure? Is there not a danger that the guarantees of the Constitution may be completely destroyed under the guise of a fictitious assent given because of the pressure exerted by the state? It is vigorously put by $\mathrm{Mr}$. Justice Sutherland in the following extract from the opinion in the Frost case:

${ }^{39}$ City and County of Denver v. New York Trust Co., 229 U. S. 123, 33 Sup. Ct. 657 (1913) ; Detroit United Ry. v. City of Detroit, 255 U. S. 17I, 4I Sup. Ct. 285 (I92I).

${ }^{30}$ Columbus Ry. P. \& L. Co. v. City of Columbus, 249 U. S. 399, 39 Sup. Ct. 349 (Igrg) ; Georgia Ry. \& P. Co. v. Town of Decatur, 262 U. S. 432, 43 Sup. Ct. 6I3 (1923); City of Opelika v. Opelika Sewer Co., 265 U. S. 215, 44 Sup. Ct. 517 (I924) ; St. Cloud Pub. Ser. Co. v. City of St. Cloud, 265 U. S. 352, 44 Sup. Ct. 492 (1924); Southern Utilities Co. v. City of Palatka, 268 U. S. 232, 45 Sup. Ct. 488 (I925); Henderson Water Co. v. Corp. Comm., 269 U. S. 278, 46 Sup. Ct. I I2 (I925). The same principle appears to be applied in Grand Rapids \& Indiana Ry. v. Osborn, I93 U. S. 17, 24 Sup. Ct. 310 (1904). 
"There is involved in the inquiry not a single power, but two distinct powers. One of these, the power to prohibit the use of the public highways in proper cases, the state possesses; and the other, the power to compel a private carrier to assume against his will the duties and burdens of a common carrier, the state does not possess. It is clear that any attempt to exert the latter, separately and substantively, must fall before the paramount authority of the Constitution. May it stand in the conditional form in which it is here made? If so, constitutional guaranties, so carefully safeguarded against direct assault, are open to destruction by the indirect, but no less effective, process of requiring a surrender, which, though in form voluntary, in fact lacks none of the elements of compulsion. Having regard to form alone, the act here is an offer to the private carrier of a privilege, which the state may grant or deny, upon a condition which the carrier is free to accept or reject. In reality, the carrier is given no choice, except a choice between the rock and the whirlpool-an option to forego a privilege which may be vital to his livelihood or submit to a requirement which may constitute an intolerable burden." 40

The doctrine of the Frost case thus viewed becomes a barrier against subversive attacks by the government, state or federal, upon the privileges vouchsafed by the Constitution. Its justification lies in the feeling that it is hard bargaining for the state to exact a surrender of those privileges in return for a grant of favor. ${ }^{41}$

On the other hand, it must be borne in mind that the effect of the doctrine, if fully established and extended to its logical boundaries, will be seriously to curtail the power of the states in advancing policies that are deemed socially desirable. If the Constitution stands in the way of the imposition of such a policy in

"Supra note 23 , at 593,46 Sup. Ct. at 607 . See also the extract quoted supra p. . Day, J., in Baltic Min. Co. v. Mass., supra note 17 , at 83,34 Sup. Ct. at I8 (I913), said: "For example, a state may not say to a foreign corporation, you may do business within our borders if you permit your property to be taken without due process of law, or you may transact business in interstate commerce subject to the regulatory power of the state. To allow a state to exercise such authority would permit it to deprive of fundamental right those entitled to have the protection of the Constitution in every part of the Union."

“For comment favoring this view see Oppenheim, Unconstitutional Conditions and State Power (1927) 26 MirCH. L. REv. I76. 
invitum, it seems perfectly logical for the state to buy assent thereto and to utilize as payment whatever of value may be within its control. The ever-increasing complexity of our social life, the resultant problems in the adjustment of conflicting interests, call for state interference to secure solutions deemed desirable in a constantly growing progression. The frequency with which limitations flowing from broad constitutional phrases are found to stand in the way of such solutions is attested by the reported decisions. The extent to which the bargaining power has been useful in overcoming such blockades is shown by the decisions already enumerated in which its use was affirmed. That it will be found of still greater usefulness in the future is beyond doubt. It seems particularly serviceable as a means of escape from blind alleys created by decisions under the due process and the equal protection clauses of the Fourteenth Amendment, the due process clause of the Fifth Amendment, ${ }^{42}$ and other constitutional provisions counched in general terms. That every decision rendered under language of such broad vagueness as is contained in these clauses should represent a desirable permanent restriction upon governmental power is impossible. Yet amendment of the Constitution to overcome specific decisions is impracticable and the process of correction through overruling and distinguishing past cases is slow and uncertain. The most effective way of dealing with such situations is through the bargaining power. To destroy this avenue of escape seems highly undesirable. That it involves the use of some pressure to waive constitutional privileges seems no insuperable objection so long as the pressure merely assumes the form of withholding that which the state is under no obligation to grant. As Mr. Justice Holmes aptly remarks :

"In order to enter into most of the relations of life people have to give up some of their constitutional rights. If a man makes a contract he gives up the constitutional right

\footnotetext{
2 While the decisions so far confine the application of the doctrine to state bargaining power, there is no reason to anticipate that federal immunity therefrom will continue if its wider application becomes established. Logically there is no reason for such a distinction. Surely a sale of constitutional privileges to the national government is no less reprehensible than a similar sale to a state.
} 
that previously he had to be free from the hamper that he puts upon himself." 43

So long as the surrender is freely made, without undue pressure, the law regards it as proper. The withholding of favors within one's control is not considered undue pressure. That the bargainer is the government should make no difference in this respect.

The undesirability of limiting state bargaining power by the doctrine of unconstitutional conditions may be made more apparent by consideration of contemporary social problems to the solution of which the bargaining power appears to offer an effective tool. One example may be found in "the valuation war" 44 in the field of public utilities in which the Supreme Court seems more and more to tend toward "reproduction cost" as the measure of the rate base required by due process. ${ }^{45}$ In Massachusetts, we are told, it is proposed to place the "prudent investment" standard upon a legally unexceptionable foundation by bartering therefor the power of eminent domain and authority to issue securities. ${ }^{46}$ Ribnik v. McBride ${ }^{47}$ and similar cases ${ }^{48}$ suggest another example. If a state finds itself cut off from rate regulation in a field which its policy deems ripe therefor, may it not exchange for consent to such regulation the monopolistic or semi-monopolistic position afforded to the holder of a certificate of public necessity and convenience? The Frost case apparently would deny this, although an older authority strongly implies the propriety of such procedure. $^{49}$ In the field of self-incrimination, state courts have sustained the requirement of reports from participants in auto-

${ }^{43}$ Dissenting in Power Mfg. Co. v. Saunders, supra note 18, at 497, 47 Sup. Ct. at $68 \mathrm{I}$.

"See Robinson, Duty of a Public Utility to Serve at Reasonable Rates: The "Valuation" War (1928) 6 N. C. L. REv. 243; Guernsey, Value in Confiscation Cases (1929) 77 U. OF PA. L. REv. 575. (1926).

¿McCardle v. Indianapolis Water Co., 272 U. S. 400, 47 Sup. Ct. I44

"See Robinson, supra note 44, at $27 \mathrm{I}$.

${ }^{4} 277$ U. S. 350,48 Sup. Ct. 545 (1928).

4 Tyson v. Banton, 273 U. S. 418, 47 Sup. Ct. 426 (1927) ; Williams v. Standard Oil Co., 49 Sup. Ct. II5 (I929).

${ }^{\circ}$ See Slaughter-House Cases, I6 Wall. 36 (U. S. I873). 
mobile accidents upon the state's power to demand assent thereto in return for the privilege of using motor cars upon the highways. $^{50}$ If the doctrine under discussion spreads to the state courts (and there is no reason why it should not, if federal sanction continues therefor) these decisions seem to be in danger. And one is tempted to speculate concerning the effect upon public business of a thoroughly consistent application of the doctrine. May the government enforce a favorable bargain for the purchase of goods after prices have rise? Has not the vendor been forced to barter his constitutional right to just compensation for the goods in return for the government's promise to take them?

Whether one agrees with the desirability of finding a way to escape from any particular situation mentioned as an illustration is beside the point. The important thing is that there are many social problems of which solutions, deemed desirable by the sentiment which finds expression in legislation, are blocked by judicial interpretation of broad constitutional language. One does not burn down the house to destroy a den of mice. So, a purchase of the power to deal with the specific situation seems to be a much more sensible, as well as practical, way out of such an impasse than the repeal of the entire constitutional provision. To such procedure, sanctioned by past decisions, the widened application of the doctrine of unconstitutional conditions offers a serious threat. In what way may the threatened danger to an important weapon of social control be averted?

\section{Validity of the Condition Determined by Purpose of the Constitutional Guarantee}

It seems that a distinction may be drawn between two classes of constitutional privileges. ${ }^{51}$ The first class includes those that are bound up with the working of our system of federal government; such as the right of the individual to resort to the appropriate governmental agency, state or federal, for the enforcement of his claims; or the freedom of either state or nation from en-

${ }^{\text {so }}$ People v. Rosenheimer, 209 N. Y. II5, 102 N. IE. 530 (I9I3); State v. Sterrin, 78 N. H. 220, 98 Atl. 482 (1916).

${ }^{51}$ The suggestion, though with a different application, may be found in Henderson, op. cit. silpra note 2, at I4I, 142. 
croachment by the other upon matters within the control of one, and the right of the individual to insist upon that freedom in an appropriate case; or again, the freedom of the states from attempted exercise of extra-territorial powers by each other. Here the doctrine originated, as we have seen, and here it seems to have a legitimate application. Since the operation of the governmental system set up by the Constitution, with its division of power among the several units, is involved, it seems clear that the individual should not be permitted to barter it away. The general interest in the proper working of the constitutional machine precludes this.

The second class includes those constitutional guarantees set up primarily for the benefit of the individual, such as the guarantee against deprivation of life, liberty and property without due process of law, the guarantee of the equal protection of the laws and the guarantee of just compensation for property taken for public use. Here the constitutional limitation is imposed for the protection of the individual. If, for a benefit deemed satisfactory to himself, he be willing to give up the protection which it affords, there is no general interest which demands that he retain it. In fact our whole social order rests upon the presupposition that in dealing with his fellows and with private organizations he will bargain away his constitutional immunities, and that those bargains will be given legal effect. There seems to be no reason to exclude governmental organizations from the list of those with whom he may bargain, and, as already pointed out, there are grave considerations of public policy in favor of including them. It would certainly seem that the unconstitutional condition doctrine should not be extended to this class of guarantees, and that, accordingly, the Frost case should not be followed in the future.

This does not mean a complete abandonment of these constitutional guarantees to whatever pressure government may bring to compel their surrender. Here, as in the field of private agreement, consent must be freely given. Duress, destroying the will, fettering freedom of action, vitiates consent. This principle is well illustrated by Union Pacific R. R. v. Public Comm. of 
Missouri, ${ }^{52}$ which held that consent to an unconstitutional tax upon a bond issue was not shown by the property owner's application for approval of the issue, not to be obtained without payment of the tax, where the approval was a prerequisite to the marketability of the bonds, the transaction involved refinancing of an important railroad system, and the property covered by the mortgage was of an extensive and permanent character. There the pressure brought to bear by the state was of so severe a nature, involving the destruction or serious hampering of an established business, not readily convertible into cash, that it amounted to duress, vitiating the formal consent to the application. It is possible that a similar explanation may be made of the Frost case. There was involved what appears to have leen an established investment in the business and certain of the language of the court indicates that considerations akin to duress may have influenced the decision..$^{53}$ If so, it should have been placed upon that ground. It is not clear, however, that the case is properly one of duress. There seem to have been no property values involved that might not have been salvaged on retirement from the business, and ordinarily mere denial by the state of the opportunity to engage in lucrative trade does not constitute duress. ${ }^{54}$ In any event, as duress is personal, in such a case the invalidity would be only as to those whose investment antedated the act. The decision goes too far in holding the law completely void, if its basis is that of duress.

If the views herein suggested be adopted, the decisions extending protection to foreign corporations against surrender of any constitutional privilege in return for admission to do business may be upheld on the theory that free commercial use of the corporate form of organization necessitates the abandonment of the old doctrine of exclusion. Otherwise it may be necessary

${ }^{62} 248$ U. S. 67, 39 Sup. Ct. 24 (Igr8) ; cf. Ward v. Love County, 253 U. S. 17, 40 Sup. Ct. 419 (I920).

\& "Having regard to form alone, the act here is an offer to the private carrier of a privilege which the carrier is free to accept or reject. In reality, the carrier is given no choice, except a choice between the rock and the whirlpoolan option to forego a privilege which may be vital to his livelihood or submit to a requirement which may constitute an intolerable burden." Supra note 23, at 593, 46 Sup. Ct. at 607.

${ }^{51}$ Cable v. U. S. Life Ins. Co., I9I U. S. 288, 24 Sup. Ct. 74 (1903). 
to overrule those decisions. It is not conceived, however, that the consequences of such a retrocession would be sufficiently serious to counterbalance the considerations in favor of maintaining the principle behind the numerous cases which uphold the bargaining power. As the cases now stand, the sole effect would be the overthrow of several decisions protecting foreign corporations from buying admission by the surrender of equal protection in taxation and procedure..$^{55}$ All are comparatively recent and the great expansion of corporate enterprise throughout the country suggests that the absence of judicial relief of this nature in past years has not retarded proper commercial development. There should be no hesitation on this score to return to the position marked out alike by the past decisions and by the proper scope of constitutional provisions in favor of the individual. ${ }^{56}$ The Supreme Court has been free to correct its position in the past, either through direct recession from an untenable position or through modification and limitation. ${ }^{57}$ The present status of the doctrine of unconstitutional conditions appears clearly to afford an appropriate occasion for further exercise of this attribute of judicial statesmanship.

$\varpi$ See list of cases supra note $I 8$.

60 "Some rights, no doubt, a person is not allowed to renounce, but very many he may." Holmes, J., dissenting in Power Mfg. Co. v. Saunders, stupra note I8, at 497,47 Sup. Ct. at 680 .

"See Mr. Justice Brandeis' lists of examples of modified or overruled doctrines in Washington v. W. C. Dawson \& Co., 264 U. S. 219, 238, 44 Sup. Ct. 302, 309 (1924), and in Di Santo v. Pennsylvania, 273 U. S. 34, 43, 47 Sup. Ct. 267,270 (1927). See also, on the same topic, Willis, Some Conflicting Decisions of the United States Stpreme Court (1927) I3 VA. L. REv. I55, 278. 